\title{
MANAJEMEN SISTEM PENDIDIKAN NASIONAL (Strategi dan Upaya menghadapi Tantangan Globalisasi melalui Pendidikan)
}

\author{
Asiyah \\ Dosen Institut Agama Islam Negeri Bengkulu \\ Email: asiyah65@gmail.com
}

\begin{abstract}
The management of national education is essentially an integral part of the education management system and process as a whole in achieving national education and development goals. Government policies and efforts are proposed by experts in addressing national education management issues. Implementation of basic education seen from various aspects, politics, technical education, culture and professional, it is clear that the problem of basic education management is not a small problem and cannot be placed in a simple dichotomy: centralistic vs. decentralistic. A centralized education management system has been shown to have made little progress in improving the quality of education in general. Even in certain cases, centralized management has resulted in the sterilization of creativity in educational units of various types and levels of education. To overcome the stagnation in the field of education is required a new paradigm in the field of education.
\end{abstract}

Keywords: Management education, globalization

Abstrak: Manajemen pendidikan nasional pada hakekatnya merupakan keterpaduan dari proses dan sistem manajemen pendidikan secara menyeluruh dalam mencapai tunjuan pendidikan dan pembangunan nasional. Kebijakan pemerintah dan berbagai upaya diusulkan oleh para ahli dalam mengatasi persoalan manajemen pendidikan nasional. Penyelenggaraan pendidikan dasar dilihat dari berbagai aspek, politik, teknis edukatif, budaya dan profesional, tampak dengan jelas bahwa masalah manajemen pendidikan dasar bukan merupakan masalah kecil dan tidak dapat diletakan dalam dikotomi sederhana: sentralistik vs desentralistik. Sistem manajemen pendidikan yang sentralistis telah terbukti tidak membawa kemajuan yang berarti bagi peningkatan kualitas pendidikan pada umumnya. Bahkan dalam kasus-kasus tertehtu, manajemen yang sentralistis telah menyebabkan terjadinya pemandulan kreatifitas pada satuan pendidikan pada berbagai jenis dan jenjang pendidikan. Untuk mengatasi terjadinya stagnasi di bidang pendidikan ini diperlukan adanya paradigma baru dibidang pendidikan.

Kata kunci: Manajemen pendidikan, globalisasi

\section{Pendahuluan}

Memasuki abad XXI ditandai dengan era globalisasi yang di dalamnya merupakan dunia informasi, proses komunikasi berjalan semakin intensif sehingga batas-batas negara tidak lagi menjadi penghalang dalam proses transformasi teknologi dan informasi. Dunia pada abad ini akan mengalami transformasi dalam segala aspek kehidupan manusia, sosial, budaya, dan politik. Proses transformasi itu dapat dirangkum dengan istilah globalisasi. Dalam era globalisasi ini kehidupan umat manusia, sebagian sudah dapat diramalkan arahnya, namun sebagian besar masih meru- a

NUANSA Vol. X, No. 2, Desember 2017

pakan teka-teki. Banyak pakar telah menelaah globalisasi, seperti Rosabeth Moss Kanter dalam Tilaar ${ }^{1}$ yang mengidentifikasi enam kekuatan yang mendorong proses tersebut, yaitu: (1) globalisasi dari proses industrialisasi dan teknologi, (2) globalisasi keuangan, komunikasi, dan infromasi, (3) globalisasi kekaryaan, pekerjaan, dan migrasi, (4) globalisasi efek polusi biosfer terhadap kehidupan manusia, (5) globalisasi dari perdagangan persenjataan, dan (6) globalisasi kebudayaan, konsumsi, dan media massa.

'Tilaar, Manajemen Pendidikan Nasional, Remadja Rosdakarya, Bandung, 2003, h. 45 
Perubahan besar yang berjalan teramat cepat melanda kehidupan masyarakat, bangsa, dan negara tersebut yang memaksa kita mempersiapkan diri bukan saja agar dapat tetap survive dalam kehidupan global yang penuh persaingan sehingga menuntut kerja keras dan hasil kerja yang berkualitas tinggi, tetapi juga bagaimana kita mengembangkan jati diri atau identitas kita sebagai bangsa Indonesia. Hal ini menuntut kita suatu wawasan masa depan, wawasan abad XXI. Masa depan bukan sesuatu yang menakutkan sehingga harus dihindari, tetapi merupakan peluang untuk meningkatkan taraf kehidupan kita asal kita siap menghadapinya. Menghadapi era globalisasi, diperlukan visi yang dapat mengarahkan misi,rencana, dan segala ikhtiar. Minimal ada enam komponen yang akan menentukan perubahan, yaitu: (1) adanya visi yang jelas, (2) misiberupa rumusan langkah-langkah kunci untuk mulai melakukan inisiatif, mengevaluasi dan mempertajam bentuk kegiatan untuk mencapai tujuan yang ditetapkan dalam visi, (3) rancangan kerja, (4) sumber daya, (5) keterampilan profesional, dan (6) motivasi dan insentif. ${ }^{2}$

Peningkatan kemampuan intelektual termasuk penguasaan, penerapan, dan pengembangan ilmu pengetahuan serta teknologi agar penguasaan tersebut dapat meningkatkan kualitas hidup manusia Indonesia. Selanjutnya, manusia Indonesia yang berkualitas mempunyai daya saing yang tinggi di tengah-tengah kehidupan global. Sudah tentu penguasaan intelektual tersebut selalu harus seimbang dengan peningkatan kemampuan etis dan moral serta agama sebagai sumber nilai-nilai etika dan moral.

Laporan komisi UNESCO mengenai pendidikan abad XXI menyatakan empat pilar, yaitu: learning to know, learning to do, learning to be, dan learning to live together. ${ }^{3}$ Dalam kaitan itu kesadaran lingkungan dan moral merupakan suatu tugas yang sangat penting di setiap program pendidikan nasional. Selanjutnya, dunia yang telah menyatu itu meminta setiap anggota masyarakat untuk hidup bersama dengan penuh toleransi di tengah-tengah perbedaan yang ada.

Dalam era globalisasi diperlukan jaringan komunikasi global seperti bahasa dunia (Inggris, Mandarin, dan Arab) yang merupakan bahasa mayoritas populasi penduduk dunia, perangkap komunikasi seperti komputer/internet, sikap disiplin dan ke-

${ }^{2}$ Tbid., h. 79

${ }^{3}$ Delors et. al, Learning The Treasure Within, (Paris : UNESCO Publishing, 1996), h. 85 mandirian. Dalam konteks nasional, pendidikan diharapkan menghasilkan menusia Indonesia seutuhnya yang cerdas, beriman dan bertaqwa terhadap Tuhan Yang Maha Esa, berbudi pekerti luhur, memiliki pengetahuan dan keterampilan, kesehatan jasmani dan rohani, berkepribadian yang mantap dan mandiri serta rasa tanggung jawab kemasyarakatan dan kebangsaan. ${ }^{4}$

Perkembangan ilmu pengetahuan dan teknologi telah membawa perubahan di hampir semua aspek kehidupan manusia dimana berbagai permasalahan hanya dapat dipecahkan kecuali dengan upaya penguasaan dan peningkatan ilmu pengetahuan dan teknologi. Selain manfaat bagi kehidupan manusia di satu sisi perubahan tersebut juga telah membawa manusia ke dalam era persaingan global yang semakin ketat. Agar mampu berperan dalam persaingan global, maka sebagai bangsa kita perlu terus mengembangkan dan meningkatkan kualitas sumber daya manusianya. Oleh karena itu, peningkatan kualitas sumber daya manusia merupakan kenyataan yang harus dilakukan secara terencana, terarah, intensif, efektif dan efisien dalam proses pembangunan, kalau tidak ingin bangsa ini kalah bersaing dalam menjalani era globalisasi tersebut.

Berbicara mengenai kualitas sumber daya manusia, pendidikan memegang peran yang sangat penting dalam proses peningkatan kualitas sumber daya manusia. Peningkatan kualitas pendidikanmerupakan suatu proses yang terintegrasi dengan proses peningkatan kualitas sumber daya manusia itu sendiri. Menyadari pentingnya proses peningkatan kualitas sumber daya manusia, maka pemerintah bersama kalangan swasta sama-sama telah dan terus berupaya mewujudkan amanat tersebut melalui berbagai usaha pembangunan pendidikan yang lebih berkualitas antara lain melalui pengembangan dan perbaikan kurikulum dan sistem evaluasi, perbaikan sarana pendidikan, pengembangan dan pengadaan materi ajar, serta pelatihan bagi guru dan tenaga kependidikan lainnya. Tetapi pada kenyataannya upaya pemerintah tersebut belum cukup berarti dalam meningkatkan kuailtas pendidikan. Salah satu indikator kekurang berhasilan ini ditunjukkan antara lain dengan NEM siswa untuk berbagai bidang studi pada jenjang SLTP dan SLTA yang tidak memperlihatkan kenaikan yang berarti bahkan boleh dikatakan konstan dari tahun ke tahun, kecuali pada beberapa sekolah dengan jumlah yang relatif sangat kecil.

Ada dua faktor yang dapat menjelaskan mengapa upaya perbaikan mutu pendidikan selama ini kurang atau tidak berhasil. Pertama,strategi pem- 
Asiyah | Manajemen Sistem Pendidikan Nasional 102

bangunan pendidikan selama ini lebih bersifat input oriented. Strategi yang demikian lebih bersandar kepada asumsi bahwa bilamana semua input pendidikan telah dipenuhi, seperti penyediaan buku-buku (materi ajar) dan alat belajar lainnya, penyediaan sarana pendidikan, pelatihan guru dan tenaga kependidikan lainnya, maka secara otomatis lembaga pendidikan (sekolah) akan dapat menghasilkan output (keluaran) yang bermutu sebagai mana yang diharapkan. Ternyata strategi inputoutput yang diperkenalkan oleh teori education production functiontidak berfungsi sepenuhnya di lembaga pendidikan (sekolah), melainkan hanya terjadi dalam institusi ekonomi dan industri. ${ }^{5}$

Kedua, pengelolaan pendidikan selama ini lebih bersifat macro-oriented, diatur oleh jajaran birokrasi di tingkat pusat. Akibatnya, banyak faktor yang diproyeksikan di tingkat makro (pusat) tidak terjadi atau tidak berjalan sebagaimana mestinya di tingkat mikro (sekolah). Atau dengan singkat dapat dikatakan bahwa komleksitasnya cakupan permasalahan pendidikan, seringkali tidak dapat terpikirkan secara utuh dan akurat oleh birokrasi pusat.

Pendidikan pada hakikatnya merupakan proses membangun peradaban bangsa. Oleh karena itu, pendidikan harus selalu bertumpu pada konsep pertumbuhan, pengembangan, pembaharuan, dan kelangsungannya sehingga penyelenggaraanpendidikan harus dikelola secara profesional. Mengingat pendidikan mempunyai peranyang sangat strategis dalam proses pembangunan peradaban bangsa, maka bidang pendidikan perlu komitmen nasional. Adanya dukungan pemerintah perlu ditindaklanjuti oleh Kabupaten/Kota dengan memberikan alokasi anggaran pendidikan di daerahnya sesuai dengan amanat konstitusi.

Pengesahan undang-undang Sistem Pendidikan Nasional Nomor 20 Tahun 2003 telah meletakkan dasar kebijakan pendidikan ke depan sekaligus memberikan landasan legal dalam pelaksanaannya. Sebagai produk hukum, undang-undang ini tidak hanya mengakomodasi berbagai kepentingan guna pengembangan pendidikan nasional, tetapi juga mempertimbangkan fenomena globalisasi. Pesan-pesan baru yang terkandung dalam UU Nomor 20 Tahun 2003, antara lain, memberikan dasar pengelolaan desentralisasi pendidikan, peningkatan porsi dana pendidikan, dan kecenderungan global. Desentralisasi pengelolaan pendidikan itekankan pada manajemen berbasis sekolah dan otonomi perguruan tinggi. Pemberian otonomi tidak

${ }^{5}$ Hanushek, Teori Education Production Function, (1979, 1981), h. 161 dimaksudkan untuk memberikan kebebasan saja, tetapi lebih dari itu adalah untuk memberdayakan perguruan tinggi.

\section{Rumusan Masalah}

1. Bagaimana manajemen pendidikan nasional mampu menghadapi tantangan globalisasi pendidikan?

2. Strategi apa yang tepat dalam mengatasi globalisasi dibidang pendidikan?

\section{Pembahasan}

\section{Manajemen Pendidikan Nasional}

H.A.R. Tilaar mengemukakan tentang keberhasilan pembangunan pendidikan nasional, "Kalau etape pertama berkenaan dengan berbagai target kuantitatif dalam pembangunan, yang kedua berkaitan dengan kepengaturan sistem pendidikan nasional'. Pernyataan tersebut menegaskan kepada kita tentang pentingnya manajemen pendidikan sebagai bagian dari manajemen pembangunan nasional. Manajemen pendidikan nasional sangat penting karena bukan saja pendidikan itu merupakan kebutuhan dasar manusia Indonesia, akan tetapi merupakan salah satu dinamisator pembangunan. Oleh karena itu manajemen pendidikan haruslah merupakan subsistem dri sistem manajemen pembangunan nasional. Seperti apa dan bagaimana manajemen pendidikan nasional? Di dalam tulisan ini penulis mengartikan "manajemen pendidikan" sebagai suatu kegiatan anggota mengimplikasikan adanya perencanaan atau rencana pendidikan serta kegiatan implementasinya. Ditegaskan oleh HAR. Tilaar bahwa pada dekade 90-an ini dunia menyaksikan suatu perubahan besar dalam tata kehidupan manusia dengan runtuhnya tatanan kehidupan sosial, politik dan ekonomi yang tidak berakar pada nilai-nilai kemanusiaan yang hakiki. Kecenderungan itu adalah humanisasi dri proses pembangunan, globalisasi dari masalah yang dihadapi umat manusia serta proses demokratisasi.

Pada awal abad XXI ini, dunia pendidikan di Indonesia menghadapi tiga tantangan besar. Tantangan pertama, sebagai akibat dari krisis ekonomi, dunia pendidikan dituntut untuk dapat mempertahankan hasil-hasil pembangunan pendidikan yang telah dicapai. Kedua, untuk mengantisipasi era global dunia pendidikan dituntut untuk mempersiapkan sumber daya manusia yang kompeten agar mampu bersaing dalam pasar kerja global. Ketiga, sejalan dengan diberlakukannya otonomi daerah, perlu dilakukan perubahan dan penyesuaian sistem pendidikan nasional sehingga dapat mewujudkan 
proses pendidikan yang lebih demokratis, memperhatikan keberagaman kebutuhan/keadaan daerah dan peserta didik, serta mendorong peningkatan partisipasi masyarakat.

Pada saat ini pendidikan nasional juga masih dihadapkan pada beberapa permasalahan yang menonjol (1) masih rendahnya pemerataan memperoleh pendidikan; (2) masih rendahnya kualitas dan relevansi pendidikan; dan (3) masih lemahnya manajemen pendidikan, di samping belum terwujudnya kemandirian dan keunggulan ilmu pengetahuan dan teknologi di kalangan akademisi. Ketimpangan pemerataan pendidikan juga terjadi antarwilayah geografis yaitu antara perkotaan dan perdesaan, serta antara kawasan timur Indonesia (KTI) dan kawasan barat Indonesia (KBI), dan antartingkat pendapatan penduduk ataupun antargender.

Kualitas pendidikan di Indonesia masih sangat memprihatinkan. Hal tersebut tercermin, antara lain, dari hasil studi kemampuan membaca untuk tingkat Sekolah Dasar (SD) yang dilaksanakan oleh organisasi International Educational Achievement (IEA) yang menunjukkan bahwa siswa SD di Indonesia berada pada urutan ke-38 dari 39 negara peserta studi. Sementara untuk tingkat Sekolah Lanjutan Tingkat Pertama (SLTP), studi untuk kemampuan matematika siswa SLTP di Indonesia hanya berada pada urutan ke-39 dari 42 negara, dan untuk kemampuan Ilmu Pengetahuan Alam (IPA) hanya berada pada urutan ke-40 dari 42 negara peserta.

Manajemen pendidikan nasional secara keseluruhan masih bersifat sentralistis sehingga kurang mendorong terjadinya demokratisasi dan desentralisasi penyelenggaraan pendidikan. Manajemen pendidikan yang sentralistis tersebut telah menyebabkan kebijakan yang seragam yang tidak dapat mengakomodasi perbedaan keragaman atau kepentingan daerah/sekolah/peserta-didik, mematikan partisipasi masyarakat dalam proses pendidikan, serta mendorong terjadinya pemborosan dan kebocoran alokasi anggaran pendidikan.

Sementara itu, penyebaran sumber daya manusia penelitian dengan berbagai macam dan tingkatan belum sesuai dengan kebutuhan dan tantangan yang dihadapi. Selain itu, masih dirasakan kurangnya budaya berpikir kritis, penghargaan karya cipta (HAKI) yang belum memadai, kurang efektifnya sistem kelembagaan dan perangkat perundang-undangan serta sertifikasi profesi ilmiah.

\section{Globalisasi, Humanisasi dan Demokratisasi.}

Fritjof Capra pernah mengungkapkan "Pada awal dua dasawarsa terakhir abad kedua puluh, kita menemukan diri kita berada dalam suatu krisis global yang serius, yaitu suatu krisis kompleks dan multidemensional yang segi-seginya menyentuh setiap aspek kehidupan kesehatan dan mata pencaharian, kualitas lingkungan dan hubungan sosial, ekonomi, teknologi, dan politik. Krisis ini merupakan krisis dalm dimensi-dimensi intelektual, moral dan spriritual, suatu krisis yang belum pernah terjadi sebelumnya dalam catatan sejarah manusia. Untuk pertama kalinya kita dihadapkan pada ancaman kepunahan ras manusia yang nyata dan bentuk kehidupan di planet ini." ${ }^{6}$

Kalimat-kalimat di atas adalah penggalan paragraf dari pendahuluan yang berjudul Krisis dan Transformasi, dalam bukunya Fritjof Capra yang berjudul Titik Balik Peradaban. Kalimat-kalimat di atas menggambarkan tentang globalisasi dan krisis multidimensional yang dihadapi oleh umat manusia. Tidak bisa dipungkiri bahwa kenyataan ini telah dan tengah kita alami bersama. Barangkali tidak perlu kita banyak bertanya bagi orang yang mampu berpikir pasti akan akan segera tanggap dan langsung merasakannya.

Kehidupan manusia memang sedang dihadapkan pada gejala globalisasi, dimana globalisasi ini akan menerjang siapa saja. Kalau Gelombang Tsunami menerjang mereka yang hidup di pantai dan sekitarnya maka globalisasi tidak padang bulu baik di pantai maupun dipegunungan semua akan dibabat habis. Sebetulnya apa sebenarnya globalisasi ini. Beberapa pengertian globalisasi akan memberikan pemahaman kepada kita, apa sebenarnya globalisasi ini. Menurut Engking Suwarman, dalam perkuliahan beliau menjelaskan beberapa definisi globalisasi yaitu "Proses mendunia sarat dengan perubahan yang cepat dan radikal diberbagai aspek kehidupan manusia. Proses meningkatkan tingkatan kesejahteraan masyarakat dari negara berkembang setara dengan yang ada dinegara maju. Proses menciptakan ketergantungan negara bekembang dri negara maju". Dari pengertian-pengertian tersebut selanjutnya dapat diketahui faktor-faktor pendorong globalisasi, dampaknya serta tantangan globalisasi seperti dijelaskan dalam perkuliahan. Faktor pendorongnya, menurut Engking dapat digambarkan sebagai berikut :

\footnotetext{
${ }^{6}$ Fritjof Capra, Titik Balik Peradaban,(Jakarta : Bentang Budaya 2002),

${ }^{7}$ Suwarman H, Engking, Mata Kuliah Pengelolaan Program Pendidikan Luar Sekolah, PLS UPI, Bandung, 2005
} h. 88 


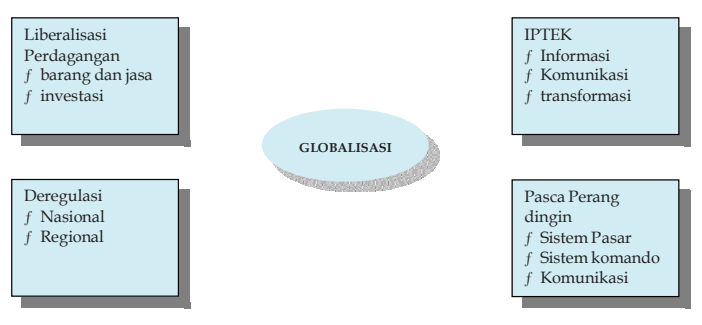

Gambar 1. Faktor Pendorong Globalisasi

Bahasan serupa seperti diungkapkan oleh Marta Tilaar. "Proses informastisasi yang cepat karerna kemajuaan teknologi semakin membuat horison kehidpan di planet dunia ini semakin meluas dan sekaligus dunia semakin mengerut". Menurutnya hal ini berarti berbagai masalah kehidupan manusia menjadi masalah global atau setidak-tidaknya tidak dapat dilepaskan dari perangaruh kejadian di belahan bumi lain, baik maslah politik, ekonomi, maupun sosial. Pendidikan bertugas untukmengembangkan kesadaran atas tanggung jawab setiap warga negara terhadap kelanjutan hidupnya, bukan saja terhadap lingkungan masyarakatnya, dan negara, juga terhadap kehidupan manusia. Dalam konstalasi global ini pendidikan berperan sangat dominan. Karena pendidikan ini akan meningkatkan taraf kecerdasan manusia. Hanya manusia yang cerdaslah yang mampu menghadapi tantangan globalisasi ini.

Tantangan lain yang mewarnai kehidupan manusai dewasa ini adalah kearah dunia yang lebih mementingkan nilai-nilai kemanusiaan, baik dalam usahanya untuk pengaturan kehidupan politik maupun sosial ekonomi. Hancurnya sistem pemerintahan yang mementingkan kekuasaan atau otoriter merupakan wujud keinginan manusia utnuk menuntuk kehidupan kemerdekaan sejati. Dalam bidang kesejahteraan misalnya The World Summit for Children di PBB menunjukkan kepedulian pemerintah terhadap penyelamatan generasi muda terutama nasim anak-anak sebagai generasi penerus abab 21. Usaha yang mementingkan nilai-nilai kemanusiaan dalam pendidikan telah melahirkan kembali pendekatan pendidikan yang mementingkan pengembangan kreativitas dalam kepribadian anak. Inilah disebut gerakan humanisasi dalam proses pendidikan. Gerakan humnaisasi ini meminta reformasi yang mendasar dalam pendidikan dalam metodologi belajr sampai dengan manajemen dan perencanaan pendidikan. Disinyalir masih banyak negara yang belum siap untuk menghadapi perubahan global, hal ini menuntut reformasi pendidikan yang meminta pendekatan baru mengenai makna kehidupan, restrukturisasi pendidikan nasional, penyesuaian peranan pendidikan dalam dunia yang berkembang. Semua pemikiran ini meminta penilaian kembali terhdap tujuan pendidikan, kurikulum, proses pendidikan, serta restrukturisasi manajemen pendidikan.

Humanisasi kehidupan manusia berkaitan erat dengan demokratisasi kehidupan manusia. Demokrasi adalah penghormatan kepda nilai-nilai kemanusiaan. Demorasi ini memungkinkan kreativitas manusia dalam peningkatan kehidupannya. Demokratisasi pendidikan mempunyai dampak yang sangat besar dalam proses perencanaan dan manajemen pendidikan. Dalam hal ini menuntut perubahan dari sistem perencanaan dan manajemen pendidikan yang birokratik menjadi sistem perencanaan dan manajemen yang terbuka.

Kenyataanya di Indonesia masih kental dengan sistem manajemen pendidikan yang sentralistik dan birokratik. Di masa globalisasi ini sistem manajemen yang demikian sudah tidak sesuai lagi. Sistem perencanaan dan manajemen pendidikan nasional harus bersifa terbuka dan fleksibel. Oleh karenanya menuntut perubahan dari yang birokratik yang cenderung kental dengan kekuasaan berubah menjadi terbuka dan cenderung partisipatoris, artinya perencanaan dan manajemen harus melibatkan semua pihak. Dengan demikian pendidikan akan disesuaikan dengan kebutuhan riil manusia atau masyarakat.

\section{Manajemen Sistem Pendidikan SebagaiKebu- tuhan Masa Depan.}

Berbicara manajemen sistem pendidikan, maka perhatian kita arahkan pada SISMENAS, yang merupakan suatu perpaduan dari tata nilai, struktur dan proses yang merupakan himpunan usah untuk mencapai kehematan, daya guna dan hasil guna sebesar mungkin dalam menggunakan sjmber dana dan daya guna nasional dalam rangka mewujudkan tujuan nasional. Ada 3 faktor dalam sistem tersebut : yaitu manajemen sebagai faktor upaya, organisasi sebagai faktor sarana, dan administrasi sebagai faktor karsa. Ketiga faktor ini memberikan arah dan perpaduan dalam merumuskan, mengendalikan pelaksanaan, mengawasi serta menilai pelaksanaan kebijakan-kebijakan dalam usaha mencapai tujuan nasional.

Didalam SISMENAS tersusun dalam beberapa setting yang disebut tatanan dalam, yaitu Tata Laksana Pemerintahan (TLP), Tata Administrasi Negara (TAN). SISMENAS sendiri merupakan proses pengambilan keputusan berkewenangan (TPKB), hal ini terjadi pada TAN dan TLP. TPKB bisa ter- 
laksana diperlukan arus masuk yaitu dari Tata Kehidupan Masyarakat (TKM), dan melewati Tata Politi Nasional (TPN). SISMENAS secara fungsional mempunyai fungsi: yaitu pembuatan aturan, penerapan aturan dan penghakiman aturan. Selanjutnya unsur-unsur sistem dalam manajemen pendidikan nasional itu akan menjadi pedoman pelaksanaan sistem pendidikan nasional kita.

Memperhatikan begitu pentingnya manajemen sistem pendidikan dalam pelaksanaan pendidikan nasional serta menunjukkan perhatian aspek kehidupan manusia ini merupakan kebutuhan yang sangat penting dalam kehidupan manusia itu. Oleh karena itu dapat dikatakan bahwa manajemen sistem pendidikan merupakan satu kebutuhan bagi manusia di masa mendatang.

Salah satu tuntutan pembangunan nasional adalah tersedianya tenaga-tenaga yagn cakap dan terampil dalam jumlah yang memadai, maka SISDIKNAS tidak dapat melepaskan diri dari kebutuhan masyarakat terhadap tenaga-tenaga tersebut. Selanjutnya untuk memenuhi tuntutuan tersebut upaya-upaya yang dilakukan antara lain melalui penekanan pada konsep-konsep sebagai berikut:

\section{Konsep pendidikan berkelanjutan}

Ketentuan pemerintah mengenai jalur penyelenggaraan pendidikan yaitu jalur pendidikan sekolah dan pendidikan luar sekolah. Dua jalur tersebut dalam pelaksanaanya memiliki karakteristik yang berbeda. Pendidikan berkelajutan ini termasuk dalam jalur pendidikan luar sekolah, jalur pendidikan berkelanjutan tidak terbatas pada usia dan ruang sekolah secara formal. Pendidikan berkelanjutan adalah konsep pendidikan yang berlangsung sepanjang hayat, termasuk dalam konsep ini adalah bentuk pelatihan yang mempunyai ciri sebagai berikut :

a. Pelatihan mengasumsikan adanya dasar pendidikan formal. Pelatihan mempunyai konotasi keterampilan tertentu.

b. Modalitas pendidikan dan pelatihan berbeda.

c. Dimensi pengembangan perilaku berbeda.

\section{Pendidikan dan Pelatihan}

Tinjauan teoritik di atas menunjukkan bahwa pembedaan antara pendidikan (formal) dan pelatihan adalah artifisial. Keduanya saling mengisi dalam rangka pengembangan manusia Indonesia seutuhnya sebagai pelaksana pembangunan.

Memperhatikan uraian di atas maka dapat disimpulkan bahwa manajemen pendidikan sebagai kebutuhan nasional artinya bahwa manajemen pendidikan harus memperhatikan kebutuhan manusia dalam konstalasi pembangunan nasional, dimana ditemukan konsep pendidikan berkelanjutan, yaitu konsep pendidikan yang tidak mengenal batas usia dan ruang secara formal, dan merupakan konsep pendidikan sepanjang hayat.

\section{Perencanaan Manajemen Pendidikan Na- sional}

Perencanaan Pendidikan Nasional pada hakekatnya adalah bagian dari SISMENAS, Rencana manajemen pendidikan nasional merupakan subsistem dari SISMENAS.RENMENDIKNAS sebagi sub sistem SISMENAS pelaksanaannya dapat dikemukakan dalam fungsi-fungsi sebagai berikut:

i. TKM sebagai arus masukan SISDIKNAS.

Tata kehidupan masyarakat Indonesia pada umumnya dipengaruhi oleh arus globalisasi. Pengaruh-pengaruh tersebut harus disaring agar dapat memberikan dampak positif dalam pembinaan SISDIkNAS. Ada dua hal yang perlu diperhatikan dalam membendung pengaruh tersebut, pertama dari perlu dibina ketahan sistem itu sendiri, kedua ketahanan yang dimaksud adalah adalah ketahanan nasional yang berpijak pada kebudayaan nasional dan tujuan nasional.

ii. Fungsi-fungsi TKPB untuk mewujudkan kepentingan rakyat melalui SISDIKNAS.

Fungsi ini dipergunakan untukmewujudkan kepentingan masyarakat, dalam hal kepentingan rakyat untuk memperoleh pendidikan yang berkualitas. TKPB sendiri mempunyai fungsi perencanaan, pelaksanaan, pengendalian pelaksanaan, dan evaluasi pelaksanaan.

a. Administrasi SISDIKNAS

Administrasi sebagai sebagai faktor karsa dri

SISMENAS meliputi dua hal:

i. pengaturan partisipasi perorangan dan kelompok

ii. pengaturan kekuasaan dan kewenangan.

b. Manajemen SISDIKNAS

Manajemen Sisdiknas merupakan suatu proses sosial yang direkayasa untuk mencapai tujuan sisdiknas secara efisien, dan efektif dengan mengikutsertakan kerjasama, serta partisipasi seluruh masyarakat. Ada tiga hal yang penting yaitu :

i. manajemen SISDIKNAS sebagai sutu proses sosial.

ii. Rekayasa utnuk mencapai tujuan SISDIKNAS

iii. Pengikutsertaan (partisipasi) masyarakat.

Sebagi proses sosial, manajemen SISDIKNAS tidak terlepas dari SISMENAS yang pada hakekatnya mengemban kepentingan nasional atau kepent- 
ingan rakyat.

c. Organisasi SISDIKNAS.

Suatu organisasi yang efektif akan mendukung proses manajemen SISDIKNAS dalam rangka mencapai tujuan pendidikan nasional. Organisasi yang efektif akan membantu perencanaan, pengambilan keputusan berkelanjutan, pelaksanaan pengawasan.

\section{Kesimpulan}

Tantangan globalisasi yang melanda setiap bangsa memerlukan penyikapan yang bijak. Bangsa Indonesia sebagai bagian dari bangsa yang akan menerima konsekuensi tantang global tersebut, mengahadapinya dengan mempersiapkan sistem pendidikan yang terintegrasi. Sistem pendidikan yang mampu menghadapi tantangan globalisasi memerlukan satu pengelolaan yang serius. Manajemen Pendidikan Nasional menjadi salah satu alternatif dalam megatasi persoalan pendidikan nasional yang amat strategis dan komplek. Manajemen pendidikan nasional pada hakekatnya merupakan keterpaduan dari proses dan sistem manajemen pendidikan secara menyeluruh dalam mencapai tunjuan pendidikan dan pembangunan nasional. Kebijakan pemerintah dan bergai upaya diusulkan oleh para ahli dalam mengatasi persoalan manajemen pendidikan nasional. Penyelenggaraan pendidikan dasar dilihat dari berbagai aspek, politik, teknis edukatif, budaya dan profesional, tampak dengan jelas bahwa masalah manajemen pendidikan dasar bukan merupakan masalah kecil dan tidak dapat diletakan dalam dikotomi sederhana: sentralistik vs desentralistik. Sistem manajemen pendidikan yang sentralistis telah terbukti tidak membawa kemajuan yang berarti bagi peningkatan kualitas pendidikan pada umumnya. Bahkan dalam kasus-kasus tertehtu, manajemen yang sentralistis telah menyebabkan terjadinya pemandulan kreatifitas pada satuan pendidikan pada berbagai jenis dan jenjang pendidikan. Untuk mengatasi terjadinya stagnasi di bidang pendidikan ini diperlukan adanya paradigma baru dibidang pendidikan.

\section{Daftar Pustaka}

Anwar dan Matahari, (2003) Peranan Pondok Pesantren Al Basyariah dalam Mempersiapkan Santri Memiliki Daya Saing Tinggi pada Era Globalisasi, Jurnal Pendidikandan Kebudayaan, Depdiknas

Capra, Fritjof (1981), Titik Balik Peradaban, Sains, Masyarakat dan Kebangkitan Kebudayaan, Bentang, Yogyakarta.

Program Pembangunan Nasional (Propenas) Tahun 2000 - 2004 Pembangunan Pendidikan, Departemen Pendidikan Nasional Indonesia

Tilaar (2003), Manajemen Pendidikan Nasional, Remadja Rosdakarya, Bandung.

Umaedi, (1999), Manajemen Peningkatan Mutu Berbasis sekolah Sebuah pendekatan baru dalam pengelolaan sekolah untuk peningkatan mutu, Debdiknas.

Suwarman H, Engking (2005), Mata Kuliah Pengelolaan Program Pendidikan Luar Sekolah, PLS UPI, Bandung.

http://www.depdiknas.go.id/publikasi/Buletin/ Pppg_Tertulis/08_2001/manajemen_pendidikan_masa_depan.htm 
被 107 